\title{
Determine the Prevalence of Migraine in Pregnant Women Presented with Severe Headache
}

\author{
JAWAD HUSSAIN ${ }^{1}$, MUHAMMAD SAQIB ${ }^{2}$, NADIA KHAN ${ }^{3}$, SOHAIL KHAN $^{4}$, FAWAD JAN ${ }^{5}$, MUHAMMAD SHAHID IQBAL ${ }^{6}$ \\ ${ }^{1}$ Assistant Professor Neurology Department Ayub Teaching Hospital, Abbottabad \\ ${ }^{2}$ Senior Registrar Neurology department Ayub Teaching Hospital, Abbottabad \\ ${ }^{3}$ Assistant Professor Gynaecology Jinnah Hospital, Abbottabad \\ ${ }^{4}$ Assistant Professor Neurology department Rehman Medical Institute, Peshawar \\ ${ }^{5}$ Assistant Professor Neurology department Gajju Khan Medical College, Swabi \\ ${ }^{6}$ Assistant Professor Neurology department Rehman Medical Institute Hayatabad, Peshawar \\ Corresponding author :Dr. Jawad Hussain, E-mail: drjawadhussain@yahoo.com, Cell No.+923329238320
}

\begin{abstract}
Objective: The main objective of this study is to determine the prevalence of migraine in pregnant women presented with severe headache.

Study Design: Retrospective study

Place and Duration: Study was conducted at department of Neurology Ayub Teaching Hospital, Abbottabad for duration of eighteen months(from August 2019 to February 2021).

Methods: 120 pregnant women with ages 18-45 years were presented in this study. Patients' detailed demographics including age, body mass index and gestational age was recorded after taking informed written consent. Patients with severe headache were enrolled and International Classification of Headache Disorders-II criteria were used for diagnosis of migraine. Trimester of pregnancy were assessed in terms of $1^{\text {st }}$, second and third. Complete date was analyzed by SPSS 20.version.

Results: Mean age of the patients was $32.16 \pm 6.44$ years with mean BMI $25.07 \pm 2.44 \mathrm{~kg} / \mathrm{m}^{2}$. Most of the patients $70(58.3 \%)$ were from third trimester. Gestational age of the pregnant women was $22.64 \pm 11.03$ weeks. 75 $(62.5 \%)$ were from urban areas and mostly had low socio-economic status $80(66.7 \%) .45(37.5 \%)$ women were educated. $50(41.7 \%)$ cases diagnosed migraine, $35(29.17 \%)$ cases had tension type headache (TTH) while the rest were showed only severe headache among pregnant women. Most common symptom was nausea 24 (48\%), followed by vomiting $16(32 \%)$ and sensitivity to light was found in $10(20 \%)$ women.

Conclusion: In this study, we concluded with the prevalent condition for pregnant women of migraine and headache-related impairment. Migraine and headache during pregnancy are critical for diagnosis and treatment.

Keywords: Headache, Pregnancy, Migraine, Prevalence
\end{abstract}

\section{INTRODUCTION}

The most frequent main headache diseases are prevalent and affect women disproportionately at a younger age, especially during childbearing years.[1] The link between headache and sex hormones, especially oestrogen, can explain the female preferences. [2] The most common disabling primary headache disease occurs with migraine, and in pregnancy, retrospective and forward-looking studies, migraine frequency usually improves in the second quarter but migraine episodes with aura and aura without headache may not mirror that pattern. [3,-10]

Acute, serious pregnancy headache is often seen as a "red signal" and need for further research, especially in fresh beginnings.[11,-13] Due to the hypercoagulability, hormonal variables, anesthetic for the labor force and other mechemics, there may be many secondary headache disorders during this period[12].

Acute pregnant headaches are a common causes for urgent neurological examination in hospitals and often lead to diagnostic problems. Previous headaches in pregnant women are frequent and it can be difficult to differentiate between a serious headache as a manifestation of preexisting immigration and a newly developed, dangerous disease. There are no guidelines for diagnostic methods, established algorithms are not validedin this patient population, The demographics, symptomatologies and diagnoses of pregnant women tested for severe headache are rare and are described in the $[14,15]$ and clinical series. $[16,17]$
Our objective was to research many pregnant women with acute headache in the hospital to better describe population, comorbidities, symptoms, test findings, rate and risk factors.

\section{MATERIAL AND METHODS}

This retrospective study was conducted atdepartment of Neurology Ayub Teaching Hospital, Abbottabad for duration of eighteen months (from August 2019 to February 2021)and comprised of 120 patients. Patients $<18$ years of age and those did not give any written consent were excluded from this study.

120 pregnant women with ages $18-45$ years were presented in this study. Patients' detailed demographics age, body mass index and gestational age was recorded after taking informed written consent. Patients with severe headache were enrolled and International Classification of Headache Disorders-II criteria were used for diagnosis of migraine. Trimester of pregnancy was assessed in terms of $1^{\text {st }}$, second and third. Systolic and diastolic blood pressure of complete women was observed. Complete date was analyzed by SPSS 20.version. Categorical variables were assessed by percentages and frequencies.

\section{RESULTS}

Mean age of the patients was $32.16 \pm 6.44$ years with mean BMI $25.07 \pm 2.44 \mathrm{~kg} / \mathrm{m}^{2}$. Most of the patients $70(58.3 \%)$ were from third trimester. Gestational age of the pregnant women was $22.64 \pm 11.03$ weeks. $75(62.5 \%)$ were from 
urban areas and mostly had low socio-economic status 80 $(66.7 \%) .45$ (37.5\%) women were educated.(table 1)

Table 1: Baseline details of enrolled cases

\begin{tabular}{|l|l|l|}
\hline Variables & Frequency (120) & $\%$ age \\
\hline Mean age (years) & $32.16 \pm 6.44$ & - \\
\hline Mean BMI (kg/m $\left.{ }^{2}\right)$ & $25.07 \pm 2.44$ & - \\
\hline Gestational age (weeks) & $22.64 \pm 11.03$ & - \\
\hline Trimester & 30 & 25 \\
\hline First & 20 & 16.7 \\
\hline Second & 70 & 58.3 \\
\hline Third & 62.5 \\
\hline Residency & 75 & 37.5 \\
\hline Urban & 45 & 33.3 \\
\hline Rural & 66.7 \\
\hline Socio-economic status & 40 & 37.5 \\
\hline High & 80 & 62.5 \\
\hline Low & 45 \\
\hline Education Status & 75 \\
\hline Yes &
\end{tabular}

There were 50 (41.7\%) cases diagnosed migraine, 35 $(29.17 \%)$ cases had tension type headache (TTH) while the rest were showed only severe headache among pregnant women. (Table 2)

Table 2: Frequency of migraine among pregnant women

\begin{tabular}{|l|l|l|}
\hline Variables & Frequency & \%age \\
\hline Migraine & 50 & 41.7 \\
\hline TTH & 35 & 29.17 \\
\hline Only Headache & 35 & 29.17 \\
\hline Total & 120 & 100 \\
\hline
\end{tabular}

Most common symptom was nausea 24 (48\%), followed by vomiting $16(32 \%)$ and sensitivity to light was found in $10(20 \%)$ women.(Table 3)

Table 3: Association of symptoms among diagnosed migraine patients

\begin{tabular}{|l|l|l|}
\hline Symptoms & Frequency & $\%$ age \\
\hline Nausea & 24 & 48 \\
\hline Vomiting & 16 & 32 \\
\hline Sensitivity to light & 10 & 20 \\
\hline Total & 50 & 100 \\
\hline
\end{tabular}

\section{DISCUSSION}

The most common diseases in headaches involve migraine and headache $(\mathrm{TTH})$, the most common ailments that affect women who need to be consulted. Headache is the primary disorder. Several observational studies to examine primary headaches during pregnancy were undertaken. In this retrospective study 120 pregnant women with age ranges between 18-55 years were presented. Mean age of the patients was $32.16 \pm 6.44$ years with mean BMI $25.07 \pm 2.44 \mathrm{~kg} / \mathrm{m}^{2}$. Our findings showed resemblance to the previous study.[18] The age-adjusted prevalence of severe headache or migraine among women adults in the National Health Interview Survey (NHIS) was $22.3 \%$ with a $26.1 \%$ greatest prevalence among females between 6 and 44 years old. [19] In addition, the AMPP study indicated that the highest prevalence of 1-year period among those aged 18-59 was seen. In that study, $17.1 \%$ of women met diagnostic criteria for definitive migraine and an additional $5.1 \%$ met diagnostic criteria for probable migraine. [20]

Most of the patients $70(58.3 \%)$ were from third trimester. Gestational age of the pregnant women was $22.64 \pm 11.03$ weeks. $75(62.5 \%)$ were from urban areas and mostly had low socio-economic status 80 (66.7\%). 45 $(37.5 \%)$ women were educated in current study.[21] Migraine is an adult disability and more common among women than among males. This is due to the action of female sex hormones, at least partly. [22] Several studies have demonstrated the degree of a decrease in the prevalence and overall cessation, particularly during the second and third trimesters, of migraines by around half to three-fourths of female migraines[23,24]. However, we noted that roughly $41.7 \%$ migraine prevalence was reported, 35\% (29.17\%) headache (TTH) cases, whereas the remaining cases indicated serious headache among pregnant women exclusively. Semere et al [25] examined 60 pregnantfemales, including 42 obtaining neurological consultations, largely in acute care settings referred for neuroimaging throughout pregnancy. Our study was also similar to the median gestational age (24 weeks) and thirdquarter rate $(53 \%)$.

Melhado et al.[26] undertook a comprehensive forward-looking study with 1,029 pregnant women, including the International Headache Society, in a variety of obstetric environments. [27] Even though they did not target acute, severe headache, a new start or new kind of pregnancy was encountered in a subset of 76 women, $52.6 \%$ of whom were secondary headache. Migraine $(41.7 \%)$ and headache were the most prevalent diagnosis, as in our study $(29.17 \%)$. The children in four categories migraine, nontramigration headaches, seizure disorders, and learning difficulties - compared the incidence of motion sickness among 222 children. Barabas, and others. In $45 \%$ of cases of childhood migraine, motion nausea was observed to be related with a $5 \%$ to $7 \%$ incidence in the other groups[29]. Motion sickness occurs in about $50 \%$ of migraine patients. The authors indicated the significant links that may have ramifications for both motor and migraine systems between the trigeminal system and vestigial nuclei. In our study most common symptom was nausea 24 (48\%), followed by vomiting $16(32 \%)$ and sensitivity to light was found in $10(20 \%)$ women.[30,31]

Our study results and prior literature show a high migraine prevalence in pregnant women. Our finding that $41.7 \%$ of women with migraines suffered from early pregnancy headaches further reflects the economic and physical effects of migraine on pregnant women.

\section{CONCLUSION}

In this study, we concluded with the prevalent condition for pregnant women of migraine and headache-related impairment. Migraine and headache during pregnancy are critical for diagnosis and treatment.

\section{REFERENCE}

1. Robbins MS, Lipton RB. The epidemiology of primary headache disorders. SeminNeurol 2010;30:107-119.

2. Zacur HA. Hormonal changes throughout life in women. Headache 2006;46(suppl 2):S49-S54. 
3. Melhado EM, Maciel JA, Jr, Guerreiro CA. Headache during gestation: evaluation of 1101 women. Can J NeurolSci 2007;34:187-192

4. Granella F, Sances G, Zanferrari C, Costa A, Martignoni E, Manzoni GC. Migraine without aura and reproductive life events: a clinical epidemiological study in 1300 women. Headache 1993;33:385-389.

5. Scharff L, Marcus DA, Turk DC. Headache during pregnancy and in the postpartum: a prospective study. Headache 1997;37:203-210.

6. Marcus DA, Scharff L, Turk D. Longitudinal prospective study of headache during pregnancy and postpartum. Headache 1999;39:625-632.

7. Granella F, Sances G, Pucci E, Nappi RE, Ghiotto N, Napp G. Migraine with aura and reproductive life events: a case control study. Cephalalgia 2000;20:701-707. 8. Sances G, Granella F, Nappi RE, et al. Course of migraine during pregnancy and postpartum: a prospective study. Cephalalgia 2003;23:197-205.

8. Manzoni GC, Farina S, Granella F, Alfieri M, Bisi M. Classic and common migraine suggestive clinical evidence of two separate entities. FunctNeurol 1986;1:112-122.

9. Russell MB, Rasmussen BK, Fenger K, Olesen J. Migraine without aura and migraine with aura are distinct clinical entities: a study of four hundred and eighty-four male and female migraineurs from the general population. Cephalalgia 1996;16:239-245.

10. Lipton RB, Silberstein SD, Dodick D. Overview of diagnosis and classification. In: Silberstein SD, Lipton RB, Dodick D, editors. Wolff's Headache and Other Head Pain, 8th ed Oxford, UK: Oxford University Press; 2008:29-43.

11. Contag SA, Mertz HL, Bushnell CD. Migraine during pregnancy: is it more than a headache? Nat Rev Neurol 2009;5:449-456.

12. De Luca GC, Bartleson JD. When and how to investigate the patient with headache. SeminNeurol 2010;30:131-144.

13. Von Wald $T$, Walling AD. Headache during pregnancy. ObstetGynecolSurv 2002;57:179-185.

14. Martin SR, Foley MR. Approach to the pregnant patient with headache. ClinObstetGynecol 2005;48:2-11.

15. Ramchandren S, Cross BJ, Liebeskind DS. Emergent headaches during pregnancy: correlation between neurologic examination and neuroimaging. AJNR Am J Neuroradiol 2007;28:1085-1087.

16. Frederick IO, Qu C, Enquobahrie DA, et al. Lifetime prevalence and correlates of migraine among women in a pacific northwest pregnancy cohort study. Headache. 2014;54(4):675-685.

17. National Center for Health Statistics. National Health Interview Survey, 2011: With Special Feature on Socioeconomic Status and Health. Hyattsville, MD: Public Health Service; 2012

18. Lipton RB, Bigal ME, Diamond M, Freitag F, Reed ML, Stewart WF AMPP Advisory Group. Migraine prevalence, disease burden, and the need for preventive therapy. Neurology. 2007;68:343-349

19. Robbins MS, Farmakidis C, Dayal AK, Lipton RB. Acute headache diagnosis in pregnant women: a hospital-based study. Neurology. doi:10.1212/WNL.0000000000001954

20. Granella F, Sances G, Zanferrari C, Costa A, Martignoni E, Manzoni GC. Migraine without aura and reproductive life events: a clinical epidemiological study in 1300 women. Headache. 1993;33:385-389

21. Maggioni F, Alessi C, Maggino T, Zanchin G. Headache during pregnancy. Cephalalgia. 1997;17:756-759

22. Kvisvik EV, Stovner LJ, Helde G, Bovim G, Linde M Headache and migraine during pregnancy and puerperium: the MIGRA-study. J Headache Pain. 2011;12:443-451

23. Semere LG, McElrath TF, Klein AM. Neuroimaging in pregnancy: a review of clinical indications and obstetric outcomes. J Matern Fetal Neonatal Med 2013;26:1371-1379

24. Melhado EM, Maciel JA, Jr, Guerreiro CA. Headache during gestation: evaluation of 1101 women. Can J NeurolSci 2007;34:187-192

25. Headache Classification Subcommittee of the International Headache Society. The International Classification of Headache Disorders: 2nd edition. Cephalalgia 2004;24(suppl 1):9-160.

26. Barabas G, Matthews WS, Ferrari M. Childhood migraine and motion sickness. Pediatrics. 1983;72:188-190

27. Marcus DA, Furman JM, Balaban CD. Motion sickness in migraine sufferers. Expert OpinPharmacother. 2005;6:26912697

28. Contag SA, Mertz HL, Bushnell CD. Migraine during pregnancy: is it more than a headache? Nat Rev Neurol. 2009;5(8):449-456.

29. Goadsby PJ, Goldberg J, Silberstein SD. Migraine in pregnancy. BMJ. 2008;336(7659):1502-1504. 